\title{
The prevalence of insulin resistance in patients with $\beta$-thalassemia major at Cipto Mangunkusumo Hospital
}

\author{
Caroline Mulawi, MD; Bambang Tridjaja, MD; Maria Abdulsalam, MD; Zakiudin Munasir, MD
}

\begin{abstract}
Background Diabetes mellitus is a common complication in patients with thalassemia major. Iron overload plays an important role by damaging the pancreatic $\beta$-cell and the liver cell, with the consequences of insulin deficiency and insulin resistance. Family history of diabetes mellitus is one of the critical factors for the development of glucose metabolism derangement. However, the pathogenesis of glucose metabolism derangement remains unclear.

Objective To evaluate the prevalence of impaired glucose tolerance, diabetes mellitus, and insulin resistance in patients with $\beta$ thalassemia major treated in the Thalassemia Outpatient Clinic, Department of Child Health, Cipto Mangunkusumo Hospital, Jakarta.

Methods This was a descriptive cross sectional study conducted in May 2002. Forty-eight subjects aged 10 to 18 years, grouped by total volume of transfusions and family history of diabetes mellitus, underwent an oral glucose tolerance test (OGTT), serum transferrin saturation, and insulin level examinations. Insulin resistance was calculated from fasting plasma glucose and insulin concentrations using the homeostasis model assessment (HOMA).

Results One of 48 patients (2\%) had impaired glucose tolerance at the age of 17 years. Diabetes mellitus occurred in three of 48 patients $(6 \%)$ at the age of 15.5 years in one patient and 18 years in two patients. Family history of diabetes mellitus was found in 2 patients with diabetes mellitus and in the only one with impaired glucose tolerance. Insulin resistance was not detected in this study. Conclusion The prevalence of glucose metabolism derangement in patients with thalassemia major was low. No insulin resistance was found in this study [Paediatr Indones 2003;43:117-120].
\end{abstract}

Keywords: thalassemia, impaired glucose tolerance, diabetes mellitus, insulin resistance.

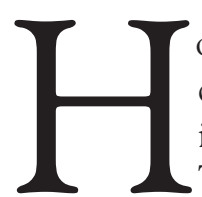

omozygous $\beta$-thalassemia is an inherited disorder of hemoglobin resulted from an imbalance of $\beta$-globin chain synthesis. ${ }^{1}$ The most important cause of anemia in $\beta$-thalassemia is ineffective erythropoiesis with intramedullary destruction of a variable proportion of the developing red cell precursors. ${ }^{2}$ The only treatment available in developing countries for thalassemic patients is regular blood transfusions. ${ }^{2,3}$ Patients who do not receive transfusions show a two to three-fold increase in the absorption of heme iron in comparison to normal subjects. ${ }^{4}$ Regular transfusions may double the rate of iron accumulation. ${ }^{1}$ In the absence of chelating therapy, the accumulation of iron results in progressive dysfunction of the heart, liver, and endocrine glands. ${ }^{5-7}$

Impaired glucose tolerance (IGT) and diabetes mellitus (DM) may be the consequences of $\beta$-cell destruction secondary to iron overload, insulin resistance, hepatitis virus infection (mainly hepatitis C) and genetic factors. ${ }^{1}$ Sanctis et al found that $5-15 \%$ of thalassemic patients suffered from IGT and DM.

From the Department of Child Health, Medical School, University of Indonesia, Cipto Mangunkusumo Hospital, Jakarta.

Request reprints to: Caroline Mulawi, MD, Department of Child Health, Medical School, University of Indonesia, Cipto Mangunkusumo Hospital, Jakarta, Indonesia. Tel. 62-21-3907740, Fax. 62-21-3907743. 
The onset of diabetes mellitus in the majority of patients occurred after the age of ten. ${ }^{1}$ Among 392 thalassemic patients aged 16 to 25 years in Karagiorga's study who underwent the OGTT, 2.3\% suffered from DM, while $17 \%$ had IGT. About $44 \%$ of the DM and $29 \%$ of the IGT had family history of diabetes mellitus in first and second degree relatives. ${ }^{5}$ Anastasi found that $20.6 \%$ of thalassemic patients aged 10-27 years suffered from DM and 30.4\% had IGT. Hyperinsulinism was detected in $37.9 \%$ of them who had IGT. 6 In 1999, Setiawan studied the prevalence of IGT and DM in thalassemic patients aged $9-22$ years at Cipto Mangunkusumo Hospital. Of 115 patients, 2.6\% had DM and $14.8 \%$ had IGT. None of them had family history of diabetes mellitus. In her study, she found no correlation neither between serum ferritin level and serum fasting glucose nor between serum ferritin level and total volume of transfusions. ${ }^{8}$

The aim of this study was to evaluate the presence of impaired glucose tolerance, diabetes mellitus, and insulin resistance in patients with $\mathrm{b}$ thalassemia major.

\section{Methods}

We conducted a descriptive cross sectional study in May, 2002. Forty-eight patients with $\beta$ thalassemia major who visited the Thalassemia Outpatient Clinic at Cipto Mangunkusumo Hospital were recruited. This study was approved by the Committee of Medical Research Ethics of Medical School, University of Indonesia. The inclusion criteria were patients with confirmed diagnosis of $\beta$ thalassemia major, aged 10 to 18 years, and their parents agreed and signed the informed consent. Questionnaire was completed by interview recording family history of diabetes mellitus in first and second degree relatives, total volume of transfusions, age of onset, and duration of illness. All patients underwent OGTT by receiving $1.75 \mathrm{~g} / \mathrm{kg}$ body weight of glucose (maximum dose $75 \mathrm{~g}$ ) after an 8 hour-fast. Venous blood samples for serum iron (SI), total iron binding capacity (TIBC), glucose and insulin determination were obtained before receiving oral glucose. At 120 minutes after oral glucose administration, glucose and insulin determination were done. All blood samples were examined at Prodia Laboratory. The criteria of the American Diabetes
Association 1998 was used to evaluate the glucose tolerance. ${ }^{9}$ Iron overload was defined when the serum transferrin saturation was $55 \%$ or more. Insulin resistance was confirmed if the homeostasis model assessment (HOMA) score was 4 or more. ${ }^{10}$ All data were transferred to SPSS 10.0 computer program.

\section{Results}

Among forty-eight thalassemic patients (27 males and 21 females), thirteen (27\%) had family history of diabetes mellitus. About $75 \%$ of the patients had already received more than 20 liters of blood transfusion. Iron overload occurred in $58 \%$ of the thalassemic patients (Table 1). Sixteen patients who received over 20 liters of blood transfusion did not have iron overload (Figure 1). One patient developed impaired glucose tolerance (2\%) at the age of 17 years and had family history of diabetes mellitus.

The total volume of blood transfusions was 87.93 liters and the serum transferrin saturation was 26.2\%. Diabetes mellitus was present in three patients $(6 \%)$, at the age of 15.5 years in one patient and 18 years in the two other patients. Two of them

Table 1. Characteristics of subjects

\begin{tabular}{ll}
\hline Number of subjects & 48 \\
\hline Age (year) & $33(69 \%)$ \\
$10-14$ & $15(31 \%)$ \\
$\quad>14-18$ & $27(56 \%)$ \\
Sex & $21(44 \%)$ \\
$\quad$ Male & \\
$\quad$ Female & $3.27(3.26)$ \\
Age of onset of thalassemia (year) & $0.2-14.0$ \\
$\quad$ Mean (SD) & \\
$\quad$ Range & $9.7(4.05)$ \\
Duration of illness (year) & $3.0-17.3$ \\
$\quad$ Mean (SD) & $13(27 \%)$ \\
$\quad$ Range & $35(73 \%)$ \\
Family history of diabetes & \\
$\quad$ Yes & $3(6 \%)$ \\
$\quad$ No & $9(19 \%)$ \\
Total volume of transfusions (liter) & $36(75 \%)$ \\
$\quad 5-10$ & $42.37(24.00)$ \\
$\quad>10-20$ & $5.5-103.0$ \\
$\quad>20$ & \\
$\quad$ Mean (SD) & $20(42 \%)$ \\
$\quad$ Range & $28(58 \%)$ \\
Transferrin saturation (\%) & $53.96(24.06)$ \\
$\quad<55$ & $9.5-122.0$ \\
$\quad \geq 55$ & \\
Mean (SD) & \\
Range &
\end{tabular}




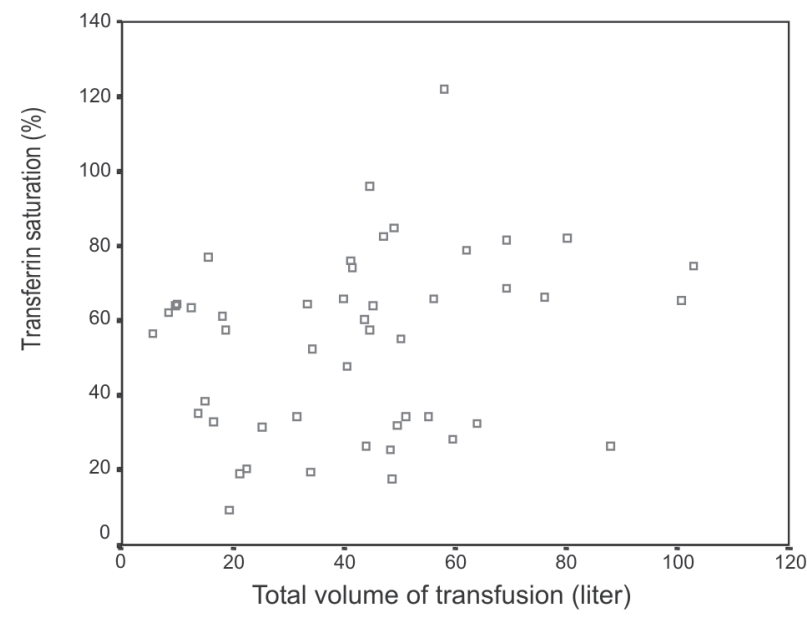

Figure 1. Total volume of transfusion and transferrin saturation

had family history of diabetes mellitus. Total volumes of blood transfusions were 44.65 liters, 103 liters, and 100.7 liters respectively. Serum transferrin saturation levels were 96\%, 74.6\%, and 65.5\% (Table 2).

After performing OGTT, we divided the patients into two groups: those with normal glucose tolerance and those with abnormal one (IGT and DM). The group with abnormal glucose tolerance had younger age of onset of thalassemia, longer duration of illness, and higher total volume of blood transfusions than that with normal glucose tolerance. In the group with abnormal glucose tolerance, the mean serum transferrin saturation was higher than in that with normal glucose tolerance (Table 3). We found no insulin resistance in all thalassemic patients, whereas only 4 patients (8\%) had abnormal glucose tolerance.

\section{Discussion}

The limitations of this study were unknown level of compliance of the use of iron-chelation and the lack of data regarding hepatitis $\mathrm{B}$ and $\mathrm{C}$ virus infection, which are the risk factors of diabetes mellitus in thalassemia.., 11

The gold standard to evaluate the sensitivity of insulin is euglycemic insulin clamp, but it is a complicated procedure. In this study, oral glucose tolerance test (OGTT) was used and it is highly correlated with the euglycemic clamp. ${ }^{12}$ Repeated blood transfusions result in accumulation of iron in the parenchyma of
TABle 2. IGT AND DM ACCORDING to AGE, FAMILY HISTORY OF DIABETES MELLITUS, TOTAL VOLUME OF BLOOD TRANSFUSIONS AND TRANSFERRIN SATURATION LEVEL

\begin{tabular}{lllll}
\hline & IGT & & DM \\
& $\mathbf{n}$ & $\%$ & $\mathbf{n}$ & $\%$ \\
\hline Age (year) & & & & \\
$\quad 10-14$ & 0 & 0 & 0 & 0 \\
$\quad>14-18$ & 1 & 2 & 3 & 6 \\
$\quad \begin{array}{l}\text { Total } \\
\text { Family history of diabetes }\end{array}$ & 1 & 2 & 3 & 6 \\
$\quad$ Yes & 1 & 2 & 2 & 4 \\
$\quad$ No & 0 & 0 & 1 & 2 \\
$\quad$ Total & 1 & 2 & 3 & 6 \\
$\begin{array}{l}\text { Total volume of transfusions (liter) } \\
\quad 5-10\end{array}$ & 0 & 0 & 0 & 0 \\
$\quad>10-20$ & 0 & 0 & 0 & 0 \\
$\quad>20$ & 1 & 2 & 3 & 6 \\
Transferrin saturation (\%) & & & & \\
$\quad<55$ & 1 & 2 & 0 & 0 \\
$\quad>55$ & 0 & 0 & 3 & 6 \\
\hline
\end{tabular}

various organs, particularly the liver, pancreas, and heart. Generally, the higher total volume of blood transfusions, the higher iron overload would be. In the sixteen subjects of this study, there was no iron overload although they had already received more than 20 liters of blood transfusion. It seems that these patients had good compliance of iron chelation therapy, unfortunately there was no available data. On the other hand, some patients who had lower total volume of blood transfusions already suffered from iron overload. The reason of this condition was unknown.

In this study, the prevalence of IGT and DM in thalassemic patients was lower than that of other studies. It seems that the different range of age and the number of samples were the reasons for the difference. The other possibility is that the test for hepatitis B or $\mathrm{C}$ virus infection which influences the prevalence of IGT and DM, was not done. Chern et al in Taiwan found that $56.3 \%$ of thalassemic patients with hepatitis $\mathrm{C}$ virus infection had DM. ${ }^{11} \mathrm{Up}$ till now, the pathogenesis of DM in thalassemia remains unclear, whether it is due to insulin deficiency, insulin resistance, or combination of them. In this study, all the abnormal glucose tolerance patients did not show insulin resistance (the HOMA calculation was under 4 in all patients). Deficiency of insulin was also not proven in this study, since all of the diabetic patients had normal fasting insulin level.

In conclusion, the prevalence of glucose metabolism derangement in thalassemic patients was low (2\% 
Table 3. Normal AND abNormal glucose tolerance according to Age OF ONSET OF THALASSEMIA, DURATION OF ILLNESS, TOTAL VOLUME OF BLOOD TRANSFUSIONS AND TRANSFERRIN SATURATION LEVEL

\begin{tabular}{llll}
\hline & Total & $\begin{array}{l}\text { Normal glucose } \\
\text { tolerance }\end{array}$ & $\begin{array}{l}\text { Abnormal glucose } \\
\text { tolerance }\end{array}$ \\
\hline $\begin{array}{l}\text { Number of subjects } \\
\text { Age of onset of thalassemia (year) }\end{array}$ & 48 & $44(92 \%)$ & $4(8 \%)$ \\
$\quad$ Mean (SD) & $3.3(3.26)$ & $3.5(3.33)$ & $1.1(0.38)$ \\
$\quad \begin{array}{l}\text { Range } \\
\text { Duration of illness (year) }\end{array}$ & $0.2-14.0$ & $0.2-14.0$ & $0.7-1.6$ \\
$\quad$ Mean (SD) & $9.7(4.1)$ & $9.5(3.8)$ & $16.2(1.0)$ \\
$\quad$ Range & $3.0-17.3$ & $3.0-17.3$ & $14.8-17.0$ \\
$\begin{array}{l}\text { Total volume of transfusions (L) } \\
\quad \text { Mean (SD) }\end{array}$ & $42.4(23.9)$ & $38.6(19.9)$ & $84.1(27.1)$ \\
$\quad$ Range & $5.5-103.0$ & $5.5-87.9$ & $44.7-103.0$ \\
$\begin{array}{l}\text { Transferrin saturation (\%) } \\
\quad \text { Mean (SD) }\end{array}$ & $53.9(24.1)$ & $5.9(23.7)$ & $65.6(29.2)$ \\
$\quad$ Range & $9.5-122.0$ & $9.5-122.0$ & $26.2-96.0$ \\
\hline
\end{tabular}

had IGT and 6\% had DM). None had insulin resistance, so it was still a question how DM developed in thalassemic patients in our study. To answer the question, further study comprising hepatitis $\mathrm{B}$ and $\mathrm{C}$ virus infection and the compliance of iron chelation therapy in thalassemic patients should be done. Diabetes screening in thalassemic patients should be performed every six months. All patients with abnormal glucose tolerance should receive intensive chelation therapy. All thalassemic patients who are seronegative to hepatitis $B$ virus should receive hepatitis $B$ vaccination.

\section{References}

1. Sanctis V, Wonke B. Growth and endocrine complications in thalassaemia major. Roma: Mediprint; 1998. p.7-42.

2. Weatherall DJ. The thalassemias. In: Beutler E, LichtmanM, Coller B, Kipps T, editors. Williams hematology. $5^{\text {th }}$ ed. New York: McGraw-Hill; 1995. p. 581-615.

3. Wahidiyat I. Transfusi darah pada thalassemia. In: Gatot D, Abdulsalam M, Windiastuti E, editors. Darah dan tumbuh kembang: aspek transfusi. Pendidikan Kedokteran Berkelanjutan Ilmu Kesehatan Anak XLI; 1998 June 24-25; Jakarta, Indonesia. p. 41-6.

4. Uzel C, Conrad ME. Absorption of heme iron. Semin Hematol 1998;35:27-34.

5. Karagiorga M, Chatzilliami A, Katsantoni A. Secondary diabetes mellitus in thalassemic patients. In: Ando S, Brancati C, editors. Endocrine disorders in thalassemia.
Physiopathological and theurapetical aspects. $2^{\text {nd }}$ ed. Berlin: Springer Verlag; 1995. p. 161-5.

6. Anastasi S, Caruso V, Cantone M, Magnano C. Insulin-dependent diabetes mellitus in a group of young people with beta-thalassemia major. In: Ando S, Brancati C, editors. Endocrine disorders in thalassemia. Physiopathological and therapeutical aspects. $2^{\text {nd }}$ ed. Berlin: Springer Verlag; 1995. p. 149-51.

7. Wonke B, Hanslip JI. Glucose intolerance and diabetes in thalassemia major. In: Ando S, Brancati C, editors. Endocrine disorders in thalassemia. Physiopathological and therapeutical aspects. $2^{\text {nd }}$ ed. Berlin: Springer Verlag; 1995. p. 65-7.

8. Setiawan S. Thalassemia beta mayor: prevalensi impaired fasting glucose dan diabetes melitus serta gambaran hematologi pada penderita yang mendapat transfusi berulang [thesis]. Jakarta: Bagian Patologi Klinik FKUI; 2000.

9. American Diabetes Association: Clinical practice recommendations 1999. Report of the Expert Committee on the diagnosis and classification of diabetes mellitus. Diabetes Care 1999;22:S5-16.

10. Haeften TW. Glucose tolerance, insulin sensitivity, and the homeostasis model assessment method. Diabetes Care 1998;21:2191.

11. Chern JP, Lin KH, Lu MY. Abnormal glucose tolerance in transfusion-dependent $b$ thalassemic patients. Diabetes Care 2001;24:850-4.

12. Matsuda M, De Fronzo R. Insulin sensitivity indices obtained from oral glucose tolerance testing. Comparison with euglycemic insulin clamp. Diabetes Care 1999;22:1462-70. 